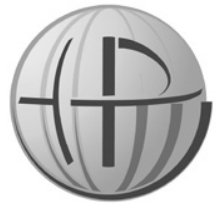

Horyzonty Polityki 2020, Vol. 11, No 37 OPEN ACCESS

\section{Bartosz KureK}

http://orcid.org/0000-0002-8554-2874

Cracow University of Economics College of Management Sciences and Quality kurekb@uek.krakow.pl

IRENEUSZ GórowsKI

http://orcid.org/0000-0002-2866-7857

Cracow University of Economics College of Management Sciences and Quality gorowski@uek.krakow.pl

DOI: 10.35765/HP.1955

\title{
Determinants of Salary Expectations - A Survey of Accounting and Controlling Students ${ }^{1}$
}

\begin{abstract}
RESEARCH OBJECTIVE: The aim of the paper is to identify and quantify selected salary expectations determinants (including gender) of Accounting and Controlling students at Cracow University of Economics.

THE RESEARCH PROBLEM AND METHODS: We conduct a survey of expected salaries among students. We use Shapiro-Wilk W test and Wilcoxon signed-rank test for initial analysis. We then build econometric linear models in which salary expectations are dependent variables, whereas GPA, holding a foreign language certificate, gender and age are independent variables. We estimate these models by OLS. We use Huber/White robust standard errors to assess statistical significance of each parameter.
\end{abstract}

THE PROCESS OF ARGUMENTATION: Graduates of accounting programmes are sought at the labour market. For cognitive purposes and educational policy implications it is of utmost importance to understand which observable factors differentiate students in their salaries' expectations.

RESEARCH RESULTS: We find a number of variables that are statistically significant and associated with the expected salary. Higher salaries for graduates of Accounting and Controlling major are expected by: students with lower GPA,

1 The publication was financed from the subsidy granted to the Cracow University of Economics. 
holders of a foreign language certificate, male students, younger students. On the contrary, lower salaries are expected by students with higher GPA, students who do not hold a foreign language certificate, female students, older students.

CONCLUSIONS, INNOVATIONS, AND RECOMMENDATIONS: Students differ among themselves - thus we observe various salary expectations. Nonetheless, some of the obtained results are puzzling. We find that female students demand lower salaries. Similarly it is surprising that students with lower GPA expect higher salaries. As a result, we recommend to further investigate determinants of salary expectations.

\section{KeYwORDS:}

salary expectations, accounting students, tertiary education, survey, econometric model

\section{INTRODUCTION}

Tertiary education provides students with professional knowledge and skills that should be recognised through appropriate salary at the market, given the demand of and the supply for labour. Universities of economics (formerly known in Poland as academies of economics) equip students not only with aforementioned "assets", but also with entrepreneurship and business skills.

Graduates of various programmes in the area of management, economics and finance may find a job in national and multinational companies, in Poland and abroad. One of these programmes is the Accounting and Controlling $(\mathrm{A} \& \mathrm{C})$ major at Cracow University of Economics (CUoE), as this programme provides knowledge and skills of a "craft" that has uniform foundations all over the world. Therefore it is relatively easy for an $\mathrm{A} \& \mathrm{C}$ graduate to accommodate and adjust to other countries working conditions and requirements and students are aware of that.

Poland is a member country of the European Union and one of the founding principles of EU is the freedom for movement of workers - compare (Kraatz, 2019). If university graduates do not receive the desired minimum salary that is adequate to their knowledge and skills, they will move abroad. In recent years we have witnessed such an emigration of highly skilled workers, when university graduates moved to European Western countries. That might result in 
a negative phenomenon known as brain drain, especially in some areas - compare (Kaczmarczyk, 2010). Poland would benefit if these graduates came back equipped with enriched professional experience, as emigration can be guided by the desire to acquire professional experience - compare (Wesołowska, 2019). Much serious problem is the brain waste, which occur when immigrants work in menial jobs - compare (Brzozowski, 2010). In the latter context T. Baas and H. Brücker (2011, p. 48) reported that more than $50 \%$ of migrants Poland in the UK held an occupational qualification which was not recognised in the host country. Consequently, it is important to investigate students' expectations of salaries not only for cognitive reasons. A number of institutions might be interested in the obtained results. One of them is the government which sets a minimum wage. An adequate level of a minimum wage may discourage graduates from emigration. Another examples are employers and specifically shared services centres which employ young graduates. An adequate level of the salary might decrease the level of personnel turnover. Third example is the academia and researchers who are investigating the process of education and inequalities at the labour market.

The aim of the paper is to identify and quantify selected salary expectations determinants (including gender).

In October 2019 we conducted a survey among full-time and parttime second and third year bachelor students and first and second year master students who studied A\&C major at CUoE. We received 341 completely filled out questionnaires. We built linear models in which salary expectations are dependent variables, and GPA, holding a foreign language certificate, gender and age are independent variables. We estimate these models by OLS and use Huber/White robust standard errors to assess statistical significance of each parameter. We use Stata/IC 14.1 for testing econometric models and for other statistical tests (Shapiro-Wilk W test, Wilcoxon signed-rank test) and Microsoft Office Excel 2013 for initial data filtering and descriptive statistics.

This paper is an extension of our previous preliminary study on salary expectations. We substantially increased the sample size and added new independent variables that appeared to be statistically significant. We contribute to the scientific literature by finding that higher salaries for graduates of A\&C major are expected by: students 
with lower GPA, holders of a foreign language certificate, male students, younger students.

The paper is organized as follows: introduction - section 1, research problem and research method (questionnaire description) - section 2 , institutional setting and data description - section 3, empirical results - section 4, conclusions and guidance for further research section 5 . Bibliography follows the last section.

\section{RESEARCH PROBLEM AND RESEARCH METHOD (QUESTIONNAIRE DESCRIPTION)}

The literature on salary expectations of students and graduates is extensive. Various researchers show a number of attitudes towards this issue. A. Sulich (2015) measures salary expectations from the first job at one of the Polish universities and shows differences among faculties. H. Stańdo-Górowska (2014) connects salary expectations with human capital model. J. Poteralski (2008) analyses threshold salary and satisfactory salary for unemployed university graduates. P.L. Roth and R.L. Clarke (1998) conduct meta-analysis of the relationship between grades and salary. J.J. Hoffman, E.B. Goldsmith and C.F. Hofacker (1992) investigate the influence of parents on salary expectations. B.G. Martin (1989), K.E. Sumner and T.J. Brown (1996) examine gender differences in salary expectations. J.E. Tromski and L.M Subich (1990) investigate the acceptability of below average salary offers.

We are especially interested in investigating determinants of salary expectations of accounting students. These students are characterized by three distinct features. First of all, accounting studies provide knowledge and skills that has common fundamental all over the world, which enables graduates to move abroad and relatively easy adjust their competences to required job qualifications. Second of all, most of accounting students learn English as the primary foreign language. Third of all, most of accounting students are females.

P. Kabalski and J. Szwajcar (2015, p. 85) notice feminization of accounting studies in Poland and point out the stereotypes about male and female professions (accounting is seen as female occupation). M. Masztalerz (2018, p. 334) on one hand confirms the quantitative 
dominance of women in Polish accounting (in the area of education, practice, politics and science), but on the other hand notices inequalities between genders in the structure of salaries. However, do women expect lower salaries, as previous research suggest? That is an important question worth investigating. Therefore we include gender as a variable suspected as being a determinants of salary expectations.

We believe that a question about the minimum net salary that would be adequate to educational background and professional experience of an $A \& C$ graduate reveals the true salary expectations of respondents. There should be a homogeneous understanding of a net salary among $A \& C$ students. On the other hand the minimum salary shows an acceptable expectation for a salary from the point of view of a particular student.

In order to investigate salary expectations of students and accompanying determinants, we distributed a questionnaire among students who were enrolled into $\mathrm{A} \& \mathrm{C}$ major at $\mathrm{CU}$.E. Respondents were presented with a scenario in which they were asked to provide expected salaries:

A student graduates from Cracow University of Economics in 2019. The student has a full time contract of employment. According to you what should be the minimum net salary that would be adequate to educational background and professional experience of a:

a) graduate with a bachelor's degree in Accounting and Controlling without any professional experience in accounting, controlling or finance?

b) graduate with a bachelor's degree in Accounting and Controlling with three years of professional experience in accounting, controlling or finance?

c) graduate with a master's degree in Accounting and Controlling without any professional experience in accounting, controlling or finance?

d) graduate with a master's degree in Accounting and Controlling with three years of professional experience in accounting, controlling or finance?

From our previous pilot research (Kurek \& Górowski, 2019) we know that salary expectations are associated with grade point 
average and holding a foreign language certificate. We also include age as a control variable. We therefore include these variables in our analysis for comparison reasons and for measuring the association of all four variables with salary expectations.

In table 1 we define our variables and in table 2 we present econometric models that we investigate. Econometric models enable us to examine the existence (in the form of statistical significance) of associations between dependent variable and independent variables. Panel A in table 2 presents econometric models with two independent variables - GPA and holding a foreign language certificate. These models were tested in the pilot research (Kurek \& Górowski, 2019). Panel B in table 2 presents advanced models, which are extended by adding two more independent variables - gender and age.

Table 1

Definitions of variables

\begin{tabular}{|l|l|}
\hline Variable & Description \\
\hline Salary B/NE & $\begin{array}{l}\text { Nonnegative continuous variable - expected net salary for the } \\
\text { graduate who completed A\&C bachelor studies and does not have } \\
\text { any professional experience (in PLN). }\end{array}$ \\
\hline Salary B/E & $\begin{array}{l}\text { Nonnegative continuous variable - expected net salary for the } \\
\text { graduate who completed A\&C bachelor studies and has three years } \\
\text { of professional experience (in PLN). }\end{array}$ \\
\hline Salary M/E & $\begin{array}{l}\text { Nonnegative continuous variable - expected net salary for the } \\
\text { graduate who completed A\&C bachelor and master studies and does } \\
\text { not have any professional experience (in PLN). }\end{array}$ \\
\hline GPA & $\begin{array}{l}\text { Nonnegative continuous variable - expected net salary for the } \\
\text { graduate who completed A\&C bachelor and master studies and has } \\
\text { three years of professional experience (in PLN). }\end{array}$ \\
\hline Lang_Cert & $\begin{array}{l}\text { Nonnegative continuous variable - grade point average. GPA is the } \\
\text { arithmetic average of all grades from the previous academic year. At } \\
\text { CUoE the following grading system scale is in force: one failing grade } \\
\text { (2.0) and six passing grades (3.0, 3.5, 4.0, 4.5, 5.0, 5.5). If a student } \\
\text { receives a failing grade, s/he has to retake the course and eventually } \\
\text { has to receive a passing grade. }\end{array}$ \\
\hline Gender & $\begin{array}{l}\text { Dichotomous variable (1 - student has a foreign language certificate, } \\
\text { 0- student does not have a foreign language certificate). Examples of } \\
\text { foreign language certificates include: LCCI, FCE, CAE, CPE, TOEFL, } \\
\text { TELC. }\end{array}$ \\
\hline Age & Dichotomous variable (1 - male, 0 - female). \\
\hline & Nonnegative discrete variable - age (in years). \\
\hline
\end{tabular}

Source: own elaboration. 
Table 2

Econometric models

\begin{tabular}{|l|c|}
\hline \multicolumn{2}{|c|}{ Panel A - models from (Kurek \& Górowski, 2019) } \\
\hline Model 1 & Salary $B / N E=\beta_{0}+\beta_{1} G P A+\beta_{2}$ Certificate $+\varepsilon$ \\
\hline Model 2 & Salary $B / E=\beta_{0}+\beta_{1} G P A+\beta_{2}$ Certificate $+\varepsilon$ \\
\hline Model 3 & Salary $M / N E=\beta_{0}+\beta_{1} G P A+\beta_{2}$ Certificate $+\varepsilon$ \\
\hline Model 4 & Salary $M / E=\beta_{0}+\beta_{1} G P A+\beta_{2}$ Certificate $+\varepsilon$ \\
\hline & Panel B - advanced models \\
\hline Model 5 & Salary $B / N E=\beta_{0}+\beta_{1} G P A+\beta_{2}$ Certificate $+\beta_{3}$ Gender $+\beta_{4}$ Age $+\varepsilon$ \\
\hline Model 6 & Salary $B / E=\beta_{0}+\beta_{1} G P A+\beta_{2}$ Certificate $+\beta_{3}$ Gender $+\beta_{4}$ Age $+\varepsilon$ \\
\hline Model 7 & Salary $M / N E=\beta_{0}+\beta_{1} G P A+\beta_{2}$ Certificate $+\beta_{3}$ Gender $+\beta_{4}$ Age $+\varepsilon$ \\
\hline Model 8 & Salary $M / E=\beta_{0}+\beta_{1} G P A+\beta_{2}$ Certificate $+\beta_{3}$ Gender $+\beta_{4}$ Age+ $+\varepsilon$ \\
\hline
\end{tabular}

Source: own deliberations.

\section{INSTITUTIONAL SETTING}

\section{AND DATA DESCRIPTION}

CUoE is one out of five public economic universities in Poland. It offers various programmes and one of the most popular majors is $A \& C$. As at October $1^{\text {st }} 2019$ there were 1215 second and third year bachelor students and first and second year master students who were enrolled into $A \& C$ programme.

In October 2019 we conducted a survey among students who were enrolled into A\&C major at CUoE. We surveyed full-time and part-time students, as well as bachelor and master students. First year bachelor students are excluded from the analysis. We distributed 607 questionnaires among students who were present during lectures and 341 questionnaires were fully filled out. In table 3 we present descriptive statistics for variables under our interest.

Average expected net salary for the graduate who completed A\&C bachelor studies without professional experience equals to 2560 PLN. Average expected net salary for the graduate who completed A\&C bachelor studies with three years of professional experience equals to 3564 PLN. Average expected net salary for the graduate who completed $\mathrm{A} \& \mathrm{C}$ bachelor and master studies without professional experience equals to 3362 PLN. Average expected net salary for the 
graduate who completed $\mathrm{A} \& \mathrm{C}$ bachelor and master studies with three years of professional experience equals to 4674 PLN. Medians equal 2500 PLN, 3500 PLN, 3000 PLN, and 4500 PLN respectively.

The minimum GPA in the analysed sample equalled to 3.40 and the maximum equalled to 5.17. Average GPA equalled to 4.35 and the median 4.32 . Only $12 \%$ of respondents hold a foreign language certificate. Male students constitute $18 \%$ of our sample and female students constitute $82 \%$ of our sample and it is interesting to note that A\&C studies are much more popular among female students. The respondents are between 19 years old and 37 years old, and their average age is 22 years old which is the same as the median age.

Table 3

Descriptive statistics of variables

\begin{tabular}{|l|c|c|c|c|c|c|c|c|}
\hline Variable & $\begin{array}{l}\text { Salary } \\
\text { B/NE }\end{array}$ & $\begin{array}{l}\text { Salary } \\
\text { B/E }\end{array}$ & $\begin{array}{l}\text { Salary } \\
\text { M/NE }\end{array}$ & $\begin{array}{l}\text { Salary } \\
\text { M/E }\end{array}$ & GPA & Lang_Cert & Gender & Age \\
\hline Minimum & 1000 & 1500 & 1600 & 2000 & 3.40 & 0 & 0 & 19 \\
\hline Maximum & 6000 & 9000 & 8000 & 15000 & 5.17 & 1 & 1 & 37 \\
\hline Average & 2560 & 3564 & 3362 & 4674 & 4.35 & 0,12 & 0,18 & 22,16 \\
\hline Q1 & 2000 & 3000 & 2700 & 3600 & 4.09 & 0 & 0 & 21 \\
\hline Median & 2500 & 3500 & 3000 & 4500 & 4.32 & 0 & 0 & 22 \\
\hline Q3 & 3000 & 4000 & 4000 & 5000 & 4.60 & 0 & 0 & 23 \\
\hline $\mathrm{n}$ & 341 & 341 & 341 & 341 & 341 & 341 & 341 & 341 \\
\hline
\end{tabular}

Source: own computations.

In table 4 we present the outcome of normality test (Shapiro-Wilk $W$ test) for dependent and independent variables. At $5 \%$ significance level we cannot reject the null hypothesis that GPA is normally distributed. All other variables are not normally distributed - at $5 \%$ we reject the null hypothesis that every other variable (individually) is normally distributed.

Table 4

Shapiro-Wilk $W$ test results for all variables

\begin{tabular}{|c|c|c|c|c|c|c|c|c|}
\hline Variable & $\begin{array}{c}\text { Salary } \\
\text { B/NE }\end{array}$ & $\begin{array}{c}\text { Salary } \\
\text { B/E }\end{array}$ & $\begin{array}{c}\text { Salary } \\
\text { M/NE }\end{array}$ & $\begin{array}{c}\text { Salary } \\
\text { M/E }\end{array}$ & GPA & $\begin{array}{c}\text { Lang- } \\
\text { Cert }\end{array}$ & Gender & Age \\
\hline p-value & $<0.00001$ & $<0.00001$ & $<0.00001$ & $<0.00001$ & 0.09875 & $<0.00001$ & 0.00007 & $<0.00001$ \\
\hline
\end{tabular}

Source: own computations. 


\section{EMPIRICAL RESULTS}

In table 5 we show mean differences and median differences for expected salaries. We test statistical significance of median differences (we do not test mean differences, as salaries are not normally distributed - compare table 4).

On one hand we obtain similar results to our previous research findings (Kurek \& Górowski, 2019) - experience is valued by respondents (Salary B/E less Salary B/NE is greater than zero and Salary M/E less Salary M/NE is greater than zero) and education is valued by respondents (Salary B/NE less Salary M/NE is greater than zero and Salary B/E less Salary B/NE is greater than zero). However, contrary to our previous findings, there is a statistically significant median difference between expected salary for the graduate who completed A\&C master studies and has no professional experience and expected net salary for the graduate who completed $A \& C$ bachelor studies with three years of professional experience. Interestingly, professional experience (three years) is valued more than master studies (which last two years).

Table 5

Mean differences and median differences for net salaries

\begin{tabular}{|c|c|c|}
\hline Variable 1 less Variable 2 & Mean difference & Median difference ( $\mathrm{p}$-value) \\
\hline \multicolumn{3}{|c|}{ Experience vs. No experience } \\
\hline Salary B/E less Salary B/NE & 1004 PLN & 1000 PLN (p-value $<0.0001$ ) \\
\hline Salary M/E less Salary M/NE & 1313 PLN & 1500 PLN $(p$-value $<0.0001)$ \\
\hline \multicolumn{3}{|c|}{ Master vs. Bachelor } \\
\hline Salary M/NE less Salary B/NE & 802 PLN & 600 PLN (p-value <0.0001) \\
\hline Salary M/E less Salary B/E & 1111 PLN & 1000 PLN ( $p$-value $<0.0001$ ) \\
\hline \multicolumn{3}{|c|}{ Master no experience vs. Bachelor experience } \\
\hline Salary M/NE less Salary B/E & -202 PLN & -100 PLN (p-value $<0.0001)$ \\
\hline
\end{tabular}

Notes: Wilcoxon signed-rank test was used to verify statistical significance of median differences (H0: median difference between pairs of observations is zero, H1: median difference between pairs of observations is different from zero).

Source: own computations.

We further present our regression results in table 6 (Panel A) and table 7 (Panel B). Panel A results confirm our initial findings - compare 
(Kurek \& Górowski, 2019) - that GPA is negatively associated with the expected salary, whereas holding a foreign language certificate is positively associated with the expected salary. In each model $(1,2$, $3,4)$ GPA is statistically significant. The coefficient sizes range from -203.94 (Salary B/NE model 1) to -927.20 (Salary M/E model 4) and are smaller in magnitude compared to our initial analysis. In two models $(2,3)$ Lang_Cert is statistically significant. In the case of statistically significant results, the coefficient sizes range from 376.51 (Salary $\mathrm{B} / \mathrm{E}$, model 2) to 337.46 (Salary M/NE, model 3) and are also smaller in magnitude compared to our initial analysis.

Table 6

Econometric models (Panel A) - results of estimation

\begin{tabular}{|c|c|c|c|c|}
\hline Model & Model 1 & Model 2 & Model 3 & Model 4 \\
\hline Variable & $\begin{array}{l}\text { Dependent v. } \\
\text { Salary B/NE }\end{array}$ & $\begin{array}{l}\text { Dependent v. } \\
\text { Salary B/E }\end{array}$ & $\begin{array}{l}\text { Dependent v. } \\
\text { Salary M/NE }\end{array}$ & $\begin{array}{l}\text { Dependent v. } \\
\text { Salary M/E }\end{array}$ \\
\hline $\begin{array}{c}\text { Independent } \\
\text { v. } \\
\text { GPA }\end{array}$ & 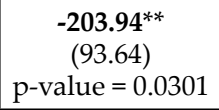 & 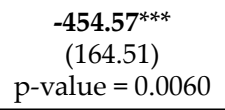 & 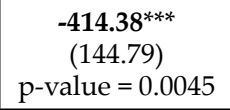 & 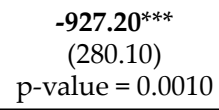 \\
\hline $\begin{array}{c}\text { Independent } \\
\text { v. } \\
\text { Lang_Cert }\end{array}$ & $\begin{array}{c}175.22 \\
(112.16) \\
\text { p-value }=0.1192\end{array}$ & $\begin{array}{c}\text { 376.51 } \\
(191.39) \\
\text { p-value }=0.0500\end{array}$ & $\begin{array}{c}337.46^{*} \\
(185.88) \\
\text { p-value }=0.0703\end{array}$ & $\begin{array}{c}525.34 \\
(323.91) \\
\text { p-value }=0.1058\end{array}$ \\
\hline Constant & $\begin{array}{c}3424.12^{* * *} \\
(415.16) \\
\text { p-value }<0.0001\end{array}$ & $\begin{array}{c}5492.34^{* * *} \\
(736.56) \\
\text { p-value }<0.0001\end{array}$ & $\begin{array}{c}5120.54^{* * *} \\
(642.86) \\
\text { p-value }<0.0001\end{array}$ & $\begin{array}{c}8638.64^{* * *} \\
(1251.19) \\
\text { p-value }<0.0001\end{array}$ \\
\hline $\mathrm{n}$ & 341 & 341 & 341 & 341 \\
\hline $\mathrm{R}^{2}$ & 0.0259 & 0.0404 & 0.0425 & 0.0585 \\
\hline F & $\begin{array}{l}\mathrm{F}(2,338)=3.06^{* *} \\
\mathrm{p} \text {-value }=0.0482\end{array}$ & $\begin{aligned} \mathrm{F}(2,338) & =5.25^{* * *} \\
\mathrm{p} \text {-value } & =0.0057\end{aligned}$ & $\begin{aligned} \mathrm{F}(2,338) & =4.93^{* * *} \\
\mathrm{p}-\text { value } & =0.0077\end{aligned}$ & $\begin{aligned} \mathrm{F}(2,338) & =5.71^{* * *} \\
\mathrm{p} \text {-value } & =0.0036\end{aligned}$ \\
\hline Mean VIF & 1.00 & 1.00 & 1.00 & 1.00 \\
\hline
\end{tabular}

Notes: for Independent variables and Constant rows the first number represents the estimated coefficient (the estimation was conducted with the OLS method) which is bolded if the parameter for the particular independent variable is statistically significant ( ${ }^{*}$ statistically significant at $10 \%,{ }^{* *}$ statistically significant at $5 \%,{ }^{* * *}$ statistically significant at $1 \%$ ), the second number shown in parentheses represents Huber/White robust standard errors and the third number represents $p$-value, $n$ is the number of observations, $R^{2}$ is the coefficient of determination, $\mathrm{F}$ is the value of statistics $\mathrm{F}$ (below is the p-value), Mean VIF is the mean variance inflation factor.

Source: own computations. 
Table 7

Econometric models (Panel B) - results of estimation

\begin{tabular}{|c|c|c|c|c|}
\hline Model & Model 5 & Model 6 & Model 7 & Model 8 \\
\hline Variable & $\begin{array}{l}\text { Dependent v. } \\
\text { Salary B/NE }\end{array}$ & $\begin{array}{l}\text { Dependent v. } \\
\text { Salary B/E }\end{array}$ & $\begin{array}{l}\text { Dependent v. } \\
\text { Salary M/NE }\end{array}$ & $\begin{array}{l}\text { Dependent v. } \\
\text { Salary M/E }\end{array}$ \\
\hline $\begin{array}{c}\text { Independent } \\
\text { v. } \\
\text { GPA }\end{array}$ & $\begin{array}{c}-122.97 \\
(87.69) \\
\text { p-value }=0.1618\end{array}$ & $\begin{array}{c}-\mathbf{3 1 3 . 0 8} \mathbf{8}^{* *} \\
(155.77) \\
\text { p-value }=0.0452\end{array}$ & 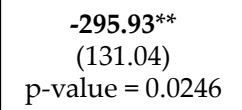 & $\begin{array}{c}-731.04^{* * *} \\
(256.69) \\
\text { p-value }=0.0047\end{array}$ \\
\hline $\begin{array}{c}\text { Independent } \\
\text { v. } \\
\text { Lang_Cert }\end{array}$ & $\begin{array}{c}\mathbf{2 1 3 . 1 2}^{*} \\
(111.65) \\
\text { p-value }=0.0571\end{array}$ & 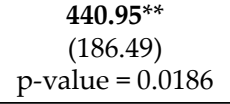 & $\begin{array}{c}\mathbf{4 4 3 . 1 1}^{* *} \\
(174.45) \\
\text { p-value }=0.0115\end{array}$ & $\begin{array}{c}\mathbf{6 8 2 . 5 8 * *} \\
(315.07) \\
\text { p-value }=0.0310\end{array}$ \\
\hline $\begin{array}{c}\text { Independent } \\
\text { v. } \\
\text { Gender }\end{array}$ & $\begin{array}{c}383.71^{* * *} \\
(99.75) \\
\text { p-value }=0.0001\end{array}$ & 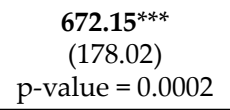 & 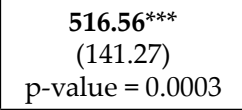 & $\begin{array}{c}\mathbf{8 7 1 . 2 4 * * *} \\
(252.26) \\
\text { p-value }=0.0006\end{array}$ \\
\hline $\begin{array}{c}\text { Independent } \\
\text { v. } \\
\text { Age }\end{array}$ & 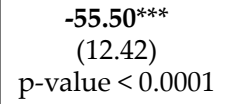 & $\begin{array}{c}\mathbf{- 9 5 . 1 4} \mathbf{4}^{* * *} \\
(26.42) \\
\text { p-value }=0.0004\end{array}$ & $\begin{array}{c}\mathbf{- 1 3 3 . 2 1}^{* * *} \\
(19.97) \\
\text { p-value }<0.0001\end{array}$ & $\begin{array}{c}\mathbf{- 2 0 2 . 2 5 * * *} \\
(38.73) \\
\text { p-value }<0.0001\end{array}$ \\
\hline Constant & $\begin{array}{c}4226.41^{* * *} \\
(513.11) \\
\text { p-value }<0.0001\end{array}$ & $\begin{array}{c}5880.25^{* * *} \\
(1167.23) \\
\text { p-value }<0.0001\end{array}$ & $\begin{array}{c}7448.78^{* * *} \\
(833.02) \\
\text { p-value }<0.0001\end{array}$ & $\begin{array}{c}12086.79^{* * *} \\
(1720.01) \\
\text { p-value }<0.0001\end{array}$ \\
\hline $\mathrm{n}$ & 341 & 341 & 341 & 341 \\
\hline $\mathrm{R}^{2}$ & 0.1120 & 0.1240 & 0.1632 & 0.1577 \\
\hline F & $\begin{array}{c}\mathrm{F}(4,336)=7.05^{* * *} \\
\mathrm{p} \text {-value }<0.0001\end{array}$ & $\begin{array}{c}\mathrm{F}(4,336)=7.27^{* * *} \\
\text { p-value }<0.0001\end{array}$ & $\begin{aligned} \mathrm{F}(4,336) & =12.64^{* * *} \\
\mathrm{p} \text {-value } & <0.0001\end{aligned}$ & $\begin{aligned} \mathrm{F}(4,336) & =9.21^{* * *} \\
\mathrm{p} \text {-value } & <0.0001\end{aligned}$ \\
\hline Mean VIF & 1.04 & 1.04 & 1.04 & 1.04 \\
\hline
\end{tabular}

Notes as in Table 6.

Source: own computations.

Results presented in Panel B also confirm our initial research findings, however, adding two additional independent variables allows us to gain deeper understanding of salary expectations determinants. As before GPA is negatively associated with the expected salary, whereas holding a foreign language certificate is positively associated with the expected salary. In three cases (models 6, 7, 8) GPA is statistically significant and in all cases (models 5, 6, 7, 8) Lang_Cert is statistically significant. In the case of statistically significant results, the coefficient sizes range from -295.93 (Salary M/NE, model 7) to -731.04 (Salary M/E, model 8) for GPA and from 213.12 (Salary B/NE, model 5) to 682.58 (Salary M/E, model 8) for Lang_Cert. 
Gender is a highly statistically significant variable in all cases (models 5, 6, 7, 8). The coefficient is positive, which means that men expect higher salaries than women - the coefficient sizes range from 383.71 (Salary B/NE, model 5) to 871.24 (Salary M/E, model 8).

In all cases (models $5,6,7,8$ ) age is statistically significant. The coefficient is negative, which means that older students expect lower salaries than younger students - the coefficient sizes range from -55.50 (Salary B/NE, model 5) to -202.25 (Salary M/E, model 8).

\section{CONCLUSIONS AND GUIDANCE FOR FURTHER RESEARCH}

Accounting students differ in their expectation of salaries. However, some trends emerge from our survey of $A \& C$ students at CUoE. Median expected net salary for the graduate who completed A\&C bachelor studies without professional experience equals to 2500 PLN. Obtaining a master's degree increases the median to the level of 3000 PLN. Having three years of professional experience increases the median even more - to the level of 3500 PLN. Having a master's degree and three years of professional experience is valued the mostthe median equals to 4500 PLN.

High GPA students expect lower salaries. Students with foreign language certificates expect higher salaries. Women expect lower salaries than men. Holding GPA, Lang_Cert and Age fixed, male students expect a net salary greater than female students of about 383.71 PLN (bachelor's degree, no experience), 672.15 PLN (bachelor's degree, three years of experience), 516.56 PLN (master's degree, no experience), 871.24 PLN (master's degree, three years of experience). Older students expect lower salaries than younger students. Holding GPA, Lang_Cert and Gender fixed, one year older students expect a net salary lower by about 55.50 PLN (bachelor's degree, no experience), 95.14 PLN (bachelor's degree, three years of experience), 133.21 PLN (master's degree, no experience), 202.25 PLN (master's degree, three years of experience).

Further studies that would explain the reasons why female students and older students expect lower salaries should be undertaken. 


\section{BiBLIOGRAPHY}

Baas, T. \& Brücker H. (2011). EU Eastern Enlargement: TheBenefits from Integration and Free Labour Movement. CESifo DICE Report, 9(2), 44-51.

Brzozowski J. (2010). Marnotrawstwo mózgów wśród wykwalifikowanych emigrantów a inwestycje w kapitał ludzki. Ekonomista, 6, 841-858.

Hoffman, J.J. \& Goldsmith, E.B. \& Hofacker, C.F. (1992). The Influence of Parents on Female Business Students' Salary and Work Hour Expectations. Journal of Employment Counseling, 29(2), 79-83.

Kabalski, P. \& Szwajcar, J. (2015). Feminizacja studiów w zakresie rachunkowości w Polsce - przyczyny i skutki. Zeszyty Teoretyczne Rachunkowości, 81(137), 85-106.

Kaczmarczyk, P. (2010). Brains on the move? Recent migration of the highly skilled from Poland and its consequence. In R. Black, G. Engbersen, M. Okólski, \& C. Panțîru (Eds.), A Continent Moving West? EU Enlargement and Labour Migration from Central and Eastern Europe (345-359). IMISCOE Research, Amsterdam University Press.

Kraatz, S. (2019). Free movement of workers. Fact Sheets on the European Union. Retrived December 01, 2019, from https://www.europarl.europa.eu/factsheets/en/sheet/41/free-movement-of-workers

Kurek, B. \& Górowski, I. (2019). Who expects high salaries? A pilot survey of salary expectations and academic achievements of Accounting and Controlling students. The Małopolska School of Economics in Tarnów Research Papers Collection, 44(4), 53-64.

Masztalerz, M. (2018). Czy rachunkowość w Polsce jest kobietą. Prace Naukowe Uniwersytetu Ekonomicznego we Wrocławiu, 503, 326-335.

Martin, B.G. (1989). Gender Differences in Salary Expectations when Current Salary Information is Provided. Psychology of Women Quarterly, 13(1), 87-96.

Poteralski, J. (2008). Oczekiwania płacowe absolwentów wyższych uczelni w województwie zachodniopomorskim w świetle badań ankietowych. Studia i Prace Wydziału Nauk Ekonomicznych i Zarzadzania, 3, 171-183.

Roth, P.L. \& Clarke, R.L. (1998). Meta-Analyzing the Relationship between Grades and Salary. Journal of Vocational Behavior, (53)3, 386-400.

Stańdo-Górowska, H. (2014). Oczekiwania płacowe studentów a model kapitału ludzkiego. Zeszyty Naukowe Uniwersytetu Ekonomicznego w Krakowie, 928(4), 51-59.

Sumner, K.E. \& Brown T.J. (1996). Men, Women, and Money: Exploring the Role of Gender, Gender-Linkage of College Major and 
Career-Information Sources in Salary Expectations. Sex Roles, 34(1112) $823-839$.

Sulich, A. (2015). Oczekiwania płacowe studentów i absolwentów Politechniki Wrocławskiej wobec pierwszego pracodawcy. e-mentor, 2(59), 24-27.

Tromski, J.E. \& Subich, L.M. (1990). College students' perceptions of the acceptability of below average salary offers. Journal of Vocational Behavior, 37(2), 196-208.

Wesołowska, M. (2019). Rozwój zawodowy jako determinanta emigracji Polaków i możliwości jego realizacji za granicą. Edukacja Ekonomistów i Menedżerów, 52(2), 187-196.

\section{Copyright and License}

This article is published under the terms of the Creative Commons Attribution - NoDerivs (CC BY- ND 4.0) License http://creativecommons.org/licenses/by-nd/4.0/ 